\title{
20. Updating a living wage estimate
}

\section{PART I. BACKGROUND}

It is necessary to update a living wage for inflation so that it retains its purchasing power and remains sufficient to support a basic but decent living standard. It is also necessary to periodically update a living wage for improvements in living standards and expectations that accompany economic development. For example, decency standards in China today are higher than they were 30 or even 10 years ago.

The issues addressed in this chapter are: (i) how to update a living wage estimate for inflation, and (ii) how often a new living wage study and new living wage estimate should be done.

\section{PART II. HOW TO UPDATE A LIVING WAGE ESTIMATE}

\subsection{Updating a Living Wage Estimate for Inflation to Ensure it Retains its Purchasing Power}

We recommend using the consumer price index (CPI) to update a living wage estimate. This should be done at least every year (and more frequently than once a year in high inflation countries, see Section 20.2). CPI is easy to use, widely accepted, and available for virtually all countries in the world. ${ }^{1}$ The usual way of measuring inflation for any period of time is to divide the CPI index for the month of interest (say July) by the CPI index for an origin month (say December). For example, if a CPI index was 216.2 in July and 210.0 in the previous December, inflation in the December to July period was $2.95 \%$ (i.e. $216.2 / 210.0$ - 1). ${ }^{2}$

We recommend first updating a living wage estimate for inflation to the end of the living wage study year. For example, if a living wage study was done in March, it would be updated for inflation to December in the same year. Then this new end of year living wage would be updated in subsequent years by further inflation. Up-to-date monthly and annual CPI inflation rates are available on most government statistical office websites. 
Table 20.1 Updating living wage estimates for inflation for four living wage studies (in local currency)

\begin{tabular}{llcccc}
\hline Country & Study date & $\begin{array}{c}\text { Original } \\
\text { gross living } \\
\text { wage per } \\
\text { month }\end{array}$ & $\begin{array}{c}\text { Gross } \\
\text { living wage, } \\
\text { December } \\
2014\end{array}$ & $\begin{array}{c}\text { Gross living } \\
\text { wage, } \\
\text { December } \\
2015\end{array}$ & Comment \\
\hline $\begin{array}{c}\text { Dominican } \\
\text { Republic }\end{array}$ & Oct. 2013 & $14,956^{\mathrm{a}}$ & $\begin{array}{c}15,258 \\
(+2.0 \%)\end{array}$ & $\begin{array}{c}15,616 \\
(+4.4 \%)\end{array}$ & $\begin{array}{c}\text { National CPI } \\
\text { used }\end{array}$ \\
\hline Kenya & March & 17,578 & $\begin{array}{c}18,285 \\
(+4.0 \%)\end{array}$ & $\begin{array}{c}19,749 \\
(+12.4 \%)\end{array}$ & $\begin{array}{c}\text { Urban CPI } \\
\text { used }\end{array}$ \\
\hline Malawi & Jan. 2014 & 35,222 & $\begin{array}{c}39,185 \\
(+11.3 \%)\end{array}$ & $\begin{array}{c}50,580 \\
(+43.6 \%)\end{array}$ & $\begin{array}{c}\text { Rural CPI } \\
\text { used }\end{array}$ \\
\hline South & May 2013 & $3,153^{\mathrm{a}}$ & $\begin{array}{c}3,431 \\
(+8.8 \%)\end{array}$ & $\begin{array}{c}3,616 \\
(+14.7 \%)\end{array}$ & $\begin{array}{c}\text { Western Cape } \\
\text { Province } \\
\text { Africa }\end{array}$ \\
& & & & & CPI used \\
\hline
\end{tabular}

Notes: Changes in taxes were not considered in this table.

a Dominican Republic and South Africa original living wage estimates were adjusted to be consistent with the approach used in this manual to calculate gross living wage.

Sources: Inflation rates from: Malawi National Statistics Office; Statistics South Africa; ILO LABORSTA and IMF for Kenya and Dominican Republic.

Government statistical websites also indicate the geographic area for which inflation was estimated and often report separate urban and rural inflation rates. Whenever possible, the CPI for the same geographic area (e.g. rural or urban) for which a living wage was estimated should be used to update a living wage for inflation. For example, we updated our living wage estimate for Western Cape Province using inflation rates for Western Cape Province and we updated our living wage estimate for rural Malawi using rural inflation rates for Malawi. ${ }^{3}$

Table 20.1 indicates how living wages for four living wage studies we have done for the Global Living Wage Coalition would be updated for inflation without considering possible changes in taxes.

\subsection{More Frequent Updates Needed for High Inflation Countries}

Waiting one year before updating a living wage in very high inflation countries would put workers in a very difficult position. In such situations, a living wage should be increased more frequently. Although there cannot be a hard and fast rule, it seems reasonable to increase a living wage more frequently than every year when inflation is more than $10 \%$ annually. Rural 
Malawi provides an example of a location where a living wage should be updated more often than annually, since its annual inflation rate has been more than $20 \%$ for several years.

\subsection{Taking Changes in Taxes and Other Mandatory Deductions into Consideration when Updating a Living Wage for Inflation}

It is necessary to take into consideration possible changes in taxes and other mandatory payroll deductions when updating a gross living wage in order to maintain the real value of take home pay. This is likely to be especially important in countries with high inflation rates, progressive tax rates, and low tax thresholds as well as in countries which changed their tax laws. It is possible, for example, for an inflation adjusted living wage to push workers earning living wage into a higher tax bracket. This means that relevant tax laws and payroll deduction rules should be reviewed and taken into consideration when adjusting a living wage for inflation.

\subsection{Updating a Living Wage for Economic Development and Improvements in Living Standards and Norms}

As countries develop, what people consider as decent improves. For this reason, a living wage is higher in China and Vietnam today than it was one, two, or three decades ago. The issue here is how often a new living wage study should be done so that the living wage represents current decency standards.

We recommend that a new living wage study be done every 5-10 years, depending on how rapidly a country is developing and living standards are improving. We recommend that a new living wage study be done at the earliest five years after an original living wage study and at the latest 10 years after an original study. This recommendation is consistent with recommendations of International Conferences of Labor Statisticians (ICLS) for how frequently to update expenditure weights used to estimate CPI. ${ }^{4} \mathrm{We}$ do not recommend doing a new living wage study every several years partly because people's expectations and norms change slowly, partly because it is difficult to measure small changes in living conditions and standards, and partly because secondary data used to help estimate a living wage such as 'household expenditure surveys may be conducted only once every five or ten years, or even at longer intervals' (ILO et al., 2004, p. 23).

We recommend that the decision of how soon to do a new living wage study in a country within the 5-10 year recommended period be based on how much real GDP per capita (i.e. GDP per capita adjusted for inflation) increased in a country. We recommend doing a new living wage study when 
inflation adjusted GDP per capita increases by $50 \%$ (or in 10 years at the latest). ${ }^{5}$ Data on real GDP per capita are available for virtually all countries from the World Bank and others; a 50\% rule is easy to understand and monitor; and a 50\% increase in real GDP per capita is large enough for living conditions and norms to improve for most people. To get an idea of how a $50 \%$ rule would work in practice, we looked at this for the past 10 years (2005-2015) for the 187 countries in the IMF database. ${ }^{6}$ We found that a new living wage benchmark would have been needed before 10 years for 24 $(13 \%)$ of the 187 countries (e.g. China in six years and India in eight years). ${ }^{7}$

\section{NOTES}

1. An alternative approach to using CPI would be to calculate and use a living wage-specific inflation rate for countries that report separate inflation rates for food and housing (using living wage-specific expenditure weights for food, housing, and other). We do not generally recommend this approach despite its advantage conceptually partly because it is more complicated, partly because such an inflation rate would not be as widely recognized or accepted as CPI, and partly because many countries do not publish separate food and housing inflation rates. However, we do suggest calculating and using a living wage-specific inflation rate in years when there is a spike in food costs in order to ensure that the real value of the living wage is maintained in such difficult years for workers.

2. It is worth noting that in locations with very large seasonal or month-to-month differences in inflation rates perhaps because of the importance of seasonal commodities, the standard approach to measuring inflation can be misleading for periods of less than one year (e.g. December to July). A way of dealing with this situation 'is to change the focus from short-term month-to-month price indices and instead focus on making year-overyear price comparisons for each month of the year' (ILO et al., 2004, p. 396), since these 'can be viewed as a seasonally adjusted annual consumer price index' (ILO et al., 2004, p. 403). Rural Malawi presents such a situation as from 2007 to 2015, the annual inflation rate for September to February averaged $59.2 \%$ whereas it was $-28.1 \%$ for March to August. For this reason, when we updated a living wage to October from previous December, we used 10/12ths of the reported year-over-year inflation rate for October.

3. IMF reports December to December inflation rates for almost all countries ('Inflation, end of period consumer prices, percentage change') on http://www.imf.org/external/pubs/ $\mathrm{ft} /$ weo/2015/01/weodata/index.aspx.

4. The 1987 ICLS recommended that expenditure 'weights should be updated periodically, and at least once every ten years' (ILO et al., 2004, p. 65) while the 2003 ICLS recommended that CPI weights be updated 'at least once every five years' (ILO et al., 2004, p. 485).

5. It is also worth considering doing a new living wage study/estimate sooner than 10 years in countries with very high inflation because high inflation disrupts lives and distorts consumer behavior as well as the economy and the job market.

6. We used a three-year average of real GDP per capita (e.g. 2005 used 2003-2005 and 2015 used 2013-2015). This smoothed out annual variations and implicitly assumed a small lag in expectations.

7. Since the $50 \%$ rule might be too stringent as it identified only $13 \%$ of countries before 10 years, we also looked at a less stringent $42.33 \%$ rule (i.e. $4 \%$ compound annual growth rate for 9 years). This less stringent rule did not make much difference as only 9 additional countries were picked up as candidates for a new benchmark before 10 years. One reason why the $50 \%$ rule did not identify more countries was the $2008 / 09$ financial crisis. 